\title{
Providing Technical and Financial Solutions to Increase Efficiency of Companies in Tehran Capital Market Based on Earlier Studies
}

\author{
Maryam Sadat Tabatabaeian \\ Faculty member of Payamenoor University
}

Doi:10.5901/mjss.2016.v7n5s1p168

\begin{abstract}
Finding appropriate way for combination and use of existing resources in order to increase efficiency is one of the questions which has been raised in recent decade in academic strategic management literature. A large number of experimental studies tested this question that which kind of solution or technical and financial strategy leads to better efficiency. One of proposed technical solution in the current work is creating diversification of products and financial solutions include optimal use of volume and type of financing, which will be discussed. Results indicate that diversity of production and financial resources management can have significant and direct impact on the company performance.
\end{abstract}

Keywords: Efficiency, Strategic management, Diversity of Production, Production Resources, Financial Resources.

\section{Introduction}

Speed of industries development and its growth in recent decades denotes that our country is transiting from a semiindustrial economy to an industrial economy. Paying attention to the production and its productivity can accelerate the industrial development and direct it in systematic and proper way. Thus, familiarization of companies with efficiency concepts and solutions for increasing it is emphasized. Hence, it can be stated that level of industrial development is considerably dependent on optimal utilization of production resources and facilities. Thus, efficiency and its continuous increase in the companies is especially important. Investigation of companies indicated that paying attention to efficiency in different companies is done in different ways. Of course, considering condition of companies and managerial policies it is natural that it is acted in different ways according to the existing situation. Current paper attempts to point out main concepts of efficient and various solutions and approaches for its increase from financial and technical views are discussed. Proposed technical solution for efficiency increase is using product diversification strategy and proposed financial solution is creating optimal volume and type of financing in the companies.

\section{Research Question}

It is important to know about how companies increase their efficiency and provide more profit. Furthermore in this research we check the technical and financial solutions to increase efficiency of companies.

\section{Objectives and Research Methodology}

This study is a Descriptive research. Descriptive research methods are pretty much as they sound they describe situations. They do not make accurate predictions, and they do not determine cause and effect. The three main ways to collect this information are: Observational, defined as a method of viewing and recording the participants.

\section{Efficiency Definition}

Efficiency means shortest time or lowest consumed energy for maximum work. Increasing efficiency level is directly dependent on the managers. Increased efficiency leads to promoting productivity and effective help to achieve organizational goals.

Efficiency is related to proper implementation of works in the organization, that is, decisions which are adopted aiming at reduction of costs, increasing production and improving product quality (Tehrani, 2008).

Initial documents and background of ergometery dates back to 1760, when French Jean Brone performed 
investigation on the operations for making pin to correct its interactions. Even one hundred years before scientific management, industry owners in France and England used a kind of work measurement for determining performance (efficiency) standards and correction of interactions. With initiation of scientific management movement early at 1900, Frederick Wincel, Teilor and Lilian Gilbrith conducted studies to enhance efficiency of workers' division of labor, improve working conditions and determine standard work time (Abtahi \& Mehrijan, 2002).

\section{Diversity of Production Strategy}

In order to economically explain that why companies tend to adopt product diversification strategy it should be noted that some studies, which have been based on domestic capital market theory and the allocation of resource efficiency, rely on positive impact of diversification. Other studies explain agency issues as motive for diversification in companies. Overall, relationship between diversification and organizational efficiency has been subject for many studies in the past years. Experts obtained three contradictory findings regarding relationship between the two variables. Some evaluated this relationship as positive, some found negative relationship between them, and others found no relationship between them. Thus, regardless of the way of diversification measurement, diversification literature has contradictory findings regarding discovery of relationship between diversification and organizational efficiency.

\section{Determine the Size and Type Suitable Financing Strategy}

Economic institutions and units seek for methods to increase efficiency and improve their liquidity for repayment of debts and confrontation with unexpected conditions in order to preserve survival in competitive markets. Fr adequate liquidity in the institutions, they can finance in different ways. Financing means providing financial resources and cash for continuation of company's activity and creating and launching development and profitable plans for these economic units. Financing is done through issuance of stocks, sale of bonds and loans and credits. They can issue stocks and raise their equity or issue bonds. Lending and borrowing are other ways of financing for institutions. Issuing bonds and borrowing increases debt of the economic unit. They way of financing by the institutions and their financing volume are issues that affect the economic performance of the unit.

Research works have obtained different conclusions; in some cases, lack of impact of technical and financial factors on efficiency of companies has been suggested, while some suggested positive and significant relationship, and in some fewer cases, inverse relationship between these factors and efficiency was obtained. Of course, statistical population and different periods of time for research works as well as using different measurement models with different variables or methods for testing hypotheses are factors for differences in findings of these research works.

Anyway, managers and owners of economic units if accept that some factors and solutions may influence efficiency of their companies, can seek for suitable ways, whether through proposed solutions in the current work or through other existing solutions in order to improve efficiency and increase efficiency of their companies.

Results obtained from previous studies are classified as follows:

Table 1: Lack of impact of financial and technical factors on company's efficiency

\begin{tabular}{|c|l|l|l|}
\hline & $\begin{array}{l}\text { Researcherl } \\
\text { Researchers name }\end{array}$ & Year & Explain the research and its results \\
\cline { 2 - 4 } $\begin{array}{c}\text { Kazerouni \& harighy } \\
\text { Technical factors } \\
\text { (Diversity of } \\
\text { Production) }\end{array}$ & 2005 & $\begin{array}{l}\text { In a research entitled "diversification of commercial transactions and its role on economic } \\
\text { development", relationship between diversification of transactions and its impact on economic } \\
\text { indexes is studied. In this research, using indigenous models, diversification of transactions as } \\
\text { alternative for product diversification beside other factors like human resources and physical } \\
\text { capital during 1359 to 1379 Is discussed. } \\
\text { Diversification of commercial transactions, due to high fluctuations, may lead to economic } \\
\text { instability in some periods, and lead to economic prosperity in some periods, thus transactions } \\
\text { diversification has no impact on economic growth (Kazeruoni \& Harighy, 2005). }\end{array}$ \\
\cline { 2 - 4 } & Tehrani \& Ahmadian & 2006 & $\begin{array}{l}\text { This research by studying different measurement selected an appropriate model to measure the } \\
\text { product diversification and check the relationship between product diversification and risk and } \\
\text { stock return in productive companies in Tehran Stock Exchange. } \\
\text { The result was that there is no tangible relationship between aspects of organizational } \\
\text { diversification and efficiency and risk of companies (Tehrani \& Ahmadian, 2006). }\end{array}$ \\
\cline { 2 - 4 } & $\begin{array}{l}\text { Boston Consulting } \\
\text { group (from Tehrani, } \\
\text { 2007) }\end{array}$ & 2007 & $\begin{array}{l}\text { In this study Sum of return to stakeholders for enlarging German companies during years 1991 } \\
\text { to 1995 is analyzed. The research find that there is no specific relationship between type and } \\
\text { level of diversification was observed and the number of good and bad focused companies in the } \\
\text { sample was the same as conglomerates (Tehrani, 2007). }\end{array}$ \\
\hline
\end{tabular}




\begin{tabular}{|c|c|c|c|}
\hline & Tehrani & 2008 & $\begin{array}{l}\text { In this research through Tehran Stock Exchange accepted companies, } 150 \text { companies were } \\
\text { selected as statistical sample among companies listed in Tehran Stock Exchange, and research } \\
\text { period was selected between years } 1381 \text { to } 1384 \text {. In order to investigate impact of diversification } \\
\text { on financial performance, diversification was defined as dependent variable and financial ratios } \\
\text { as dependent variable, and hypotheses were tested using statistical tests, and following results } \\
\text { were obtained: } \\
\text { 1. There should be an ongoing development in management of diversification oriented managers } \\
\text { and lack of proper management is one of the reasons for failure in the companies. } \\
\text { 2. Lack of skilled and experienced work labor, high launching costs or diversification of } \\
\text { companies, existing economic conditions and major goal of company for diversification (mostly } \\
\text { higher profitability) were mentioned as failure factors in diversity-oriented companies. } \\
\text { This study fined that ther is ni significant relationship between diversity and financial ratios } \\
\text { (Tehrani, 2008). }\end{array}$ \\
\hline & Mojtahedzadeh et.al & 2009 & $\begin{array}{l}\text { This study checks the effect of types and volume of financing on the companies operating } \\
\text { performance. } \\
\text { Results show that not only financing has no effect on operational performance before and after it, } \\
\text { but also type and volume of financing has no considerable effect on most criteria of operational } \\
\text { performance (Mojtahedzadeh et.al, 2009). }\end{array}$ \\
\hline \multirow[t]{2}{*}{$\begin{array}{l}\text { Financial factor } \\
\text { (level and type of } \\
\text { financing) }\end{array}$} & $\begin{array}{l}\text { Asadi and pour } \\
\text { ghorban }\end{array}$ & 2010 & $\begin{array}{l}\text { This study investigated effect of stock return on financing methods adopted by the companies. } \\
\text { The results show that there is no significant relationship between Funds from the issue of shares } \\
\text { and future return of stock (Asadi and pour ghorban, 2010). }\end{array}$ \\
\hline & Sheikh et.al & 2014 & $\begin{array}{l}\text { In this study the relationship between diversification variable as independent variable and } \\
\text { financial ratios as dependent variable was investigated using statistical tests (Sheikh et.al, 2014). }\end{array}$ \\
\hline
\end{tabular}

Table 2: Direct effect of financial and technical factors on company's efficiency

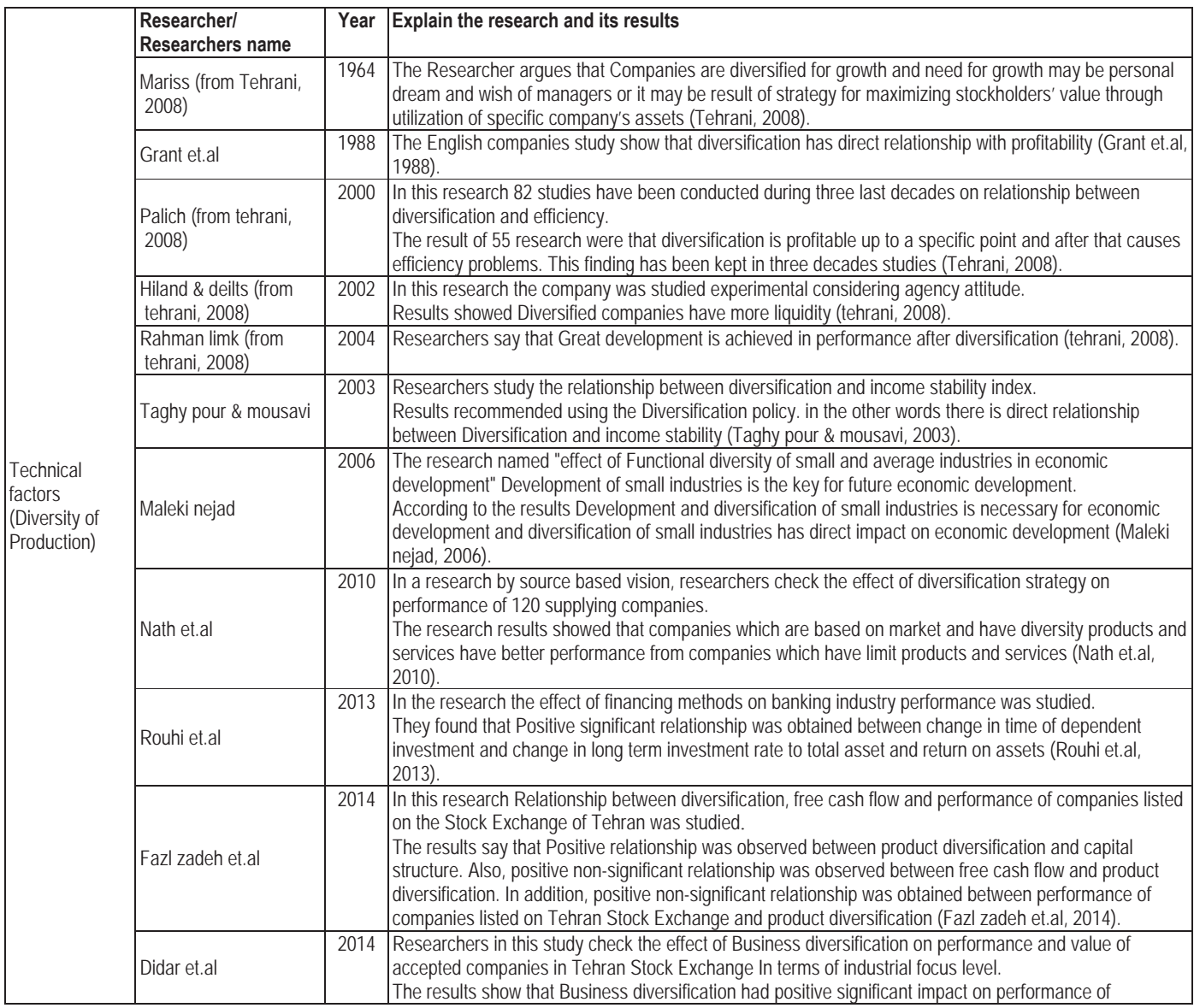




\begin{tabular}{|c|c|c|c|}
\hline & & & $\begin{array}{l}\text { companies under study and had negative non-significant impact on value of the companies under study } \\
\text { (Didar et.al, 2014). }\end{array}$ \\
\hline \multirow{8}{*}{$\begin{array}{l}\text { Financial factor } \\
\text { (level and type } \\
\text { of financing) }\end{array}$} & Mclaughlin et.al & 1996 & $\begin{array}{l}\text { Researchers studied Long term operational performance of } 960 \text { non-convertible bonds during years } 1980 \\
\text { to } 1993 . \\
\text { The results say that Companies showed considerable improvement in operational performance } \\
\text { (Mclaughlin et.al, 1996). }\end{array}$ \\
\hline & Heron \& lee & 2004 & $\begin{array}{l}\text { In this study Different ways of stock issuance for financing, like primary issuance (IPO), secondary } \\
\text { issuance, and supply the priority purchase of shares and their impact on operational performance were } \\
\text { examined. } \\
\text { The results showed that Operational performance is highly related to the type of financing (Heron \& lee, } \\
\text { 2004). }\end{array}$ \\
\hline & Casser & 2005 & $\begin{array}{l}\text { In this study Relationship between level and type of financing and past and future operational } \\
\text { performance of companies from New York Stock Exchange was studied. } \\
\text { The results showed Changes in the company's operational performance is regularly related to the type } \\
\text { and level of company's financing (Casser, 2005). }\end{array}$ \\
\hline & Abrazi et.al & 2007 & $\begin{array}{l}\text { In this research Different ways of financing and relationship between financing and firm size, fixed assets, } \\
\text { and profitability were studied. } \\
\text { According to this research results Despite of lack of significant difference in using different financing } \\
\text { methods (retained earnings, stock and debt), there is significant relationship between financing way and } \\
\text { firm size (Abrazi et.al, 2007). }\end{array}$ \\
\hline & Cheng et.al & 2007 & $\begin{array}{l}\text { In this study Relationship between company's strategic system and operational performance after initial } \\
\text { public offering in Chinese companies is studied. } \\
\text { The results showed These companies had better operational performance before initial public offering } \\
\text { compared to similar industries (Cheng et.al, 2007). }\end{array}$ \\
\hline & Molla nazari et.al & 2009 & $\begin{array}{l}\text { In this research Relationship between financing (capital increasing and banking loan) methods and } \\
\text { success or failure of companies is studied. } \\
\text { The results show that There is significant relationship between financing methods and failure in } \\
\text { companies listed on Tehran Stock Exchange, and capital increase is more effective on success of } \\
\text { companies than bank loans (Molla nazari et.al, 2009). }\end{array}$ \\
\hline & $\begin{array}{l}\text { Kordestni \& najafi } \\
\text { omran }\end{array}$ & 2010 & $\begin{array}{l}\text { In this research the Effect of different ways of financing and consuming benefits of these methods on } \\
\text { future stock return was studied. } \\
\text { Results show that Relationship between net change in total finance, net change in external finance and } \\
\text { change in net operational assets financed from internal financial resources and cumulative abnormal } \\
\text { stock return is significant, but it is positive unlike expected (Kordestni \& najafi omran, 2010). }\end{array}$ \\
\hline & Harash et.al & 2014 & $\begin{array}{l}\text { In this study Financing impact on performance of SMEs performance is studied. } \\
\text { Researchers found that Financing in SMEs affects efficiency of the companies(Harash et.al, 2014). }\end{array}$ \\
\hline
\end{tabular}

Table 3: inverse effect of financial and technical factors on company's efficiency

\begin{tabular}{|c|c|c|c|}
\hline \multirow{6}{*}{$\begin{array}{l}\text { Technical factors } \\
\text { (Diversity of } \\
\text { Production) }\end{array}$} & \begin{tabular}{|l|} 
Researcherl \\
Researchers name
\end{tabular} & Year & Explain the research and its results \\
\hline & Kang et.al & 2011 & $\begin{array}{l}\text { In this study researchers found that There is inverse relationship between level of product } \\
\text { diversification, company's performance and supplements (Kang et.al, 2011). }\end{array}$ \\
\hline & $\begin{array}{l}\text { Ramlet (from sheikh } \\
\text { et.al, 1393) }\end{array}$ & 1984 & They found Companies with more diversification have less profitability (sheikh et.al, 1393). \\
\hline & $\begin{array}{l}\text { Rajan cerwos \& zingas } \\
\text { (from sheikh et.al, } \\
\text { 1393) }\end{array}$ & 2000 & $\begin{array}{l}\text { They confirmed Internal markets indicate that companies use cash flows created by some sectors } \\
\text { to help other sectors. Internal capital markets are not efficient and it is the main reason for } \\
\text { reduction of diversification (sheikh et.al, 1393). }\end{array}$ \\
\hline & $\begin{array}{l}\text { Denis (from sheikh } \\
\text { et.al, 1393) }\end{array}$ & 2002 & $\begin{array}{l}\text { Researchers showed the Effects of industrial diversification on the company's value is negative } \\
\text { (sheikh et.al, 1393). }\end{array}$ \\
\hline & $\begin{array}{l}\text { Hushino (from tehrani } \\
\text { et.al, 1387) }\end{array}$ & 2001 & $\begin{array}{l}\text { They show that Following diversification a great decline occurs in the performance (tehrani et.al, } \\
\text { 1387). }\end{array}$ \\
\hline \multirow{3}{*}{$\begin{array}{l}\text { financial factors } \\
\text { (Diversity of } \\
\text { Production) }\end{array}$} & Mclaughlin et.al & 1996 & $\begin{array}{l}\text { Researchers studied Long term seasonal operational performance during years } 1980 \text { to } 1993 . \\
\text { They showed that Average changes in operational performance were reduced by 20\% during } 3 \\
\text { years and highest changes were experienced in performance through stock issuance (Mclaughlin } \\
\text { et.al, 1996). }\end{array}$ \\
\hline & Chi \& pejet & 2006 & $\begin{array}{l}\text { In this study Operational performance changes in Chinese companies after initial public offering } \\
\text { and relationship between operational performance and return of these companies were } \\
\text { investigated. } \\
\text { Results say that Initial public offering causes considerable reduction in profitability, sale growth rate } \\
\text { and efficiency of the company (Chi \& pejet, 2006). }\end{array}$ \\
\hline & Asadi \& pour ghorban & 2010 & $\begin{array}{l}\text { Researchers studied the effect of company's stock return on Adopted financing methods. } \\
\text { According to the results, Inverse relationship was observed between cash flow from financing } \\
\text { activities and future stock returns and, also between the proceeds of borrowing and future stock } \\
\text { returns, and between the proceeds of debt and future stock returns (Asadi \& pour ghorban, 2010). }\end{array}$ \\
\hline
\end{tabular}




\section{Conclusion}

Various factors influence increasing efficiency of companies. In the current study, one technical factor and one financial factor impact was studied and previous studies were described in terms of factors and effectiveness or ineffectiveness. According to the studies, most findings suggest direct significant relationship between mentioned factors and efficiency of companies. Managers and owners of the companies should act for management of internal mechanisms of the company including production management, new, diversified products tailored to the needs of the market and financial resource management including determining the best type of financing and determining the best size of each of these methods in order to improve company's efficiency. For example, in studies on companies listed on Tehran Stock Exchange suggested positive significant relationship between product diversification and company's performance. Also, management of volume and type of financing in Isfahan Pegah Company can lead to better performance for the company.

\section{References}

Abrazi, M; Dastgir, M, Gholi pour, A. Examining and analyzing financing methods of Tehran security exchange accepted companies, 2007, journal of economic researches, $\mathrm{N} 4$.

Abtahi, S. H. \& Mehrojan A . Methods engineering, Tehran, Ghomes, 2002, first publishing, p23.

Asadi, GH; Pourghorban, A. Relationship of financing ways with stock future return, 2010, experimental study's of financial accounting. N29, pp 139 to 154.

Casser; gavin john. external financing and firm operating performance, 2005,working paper, university of California, Berkeley.

Cheng, P; Jean, J \& Xinrong, X. expropriation, weak corporate governance and post-IPO performance: chinese evidence, 2007, advancese in financial economics, vol 12, p 237-267.

Chi, J \& carol, P. operating performance and Its relationship to market performance of chinese initial public offerings, 2006, the chinese economy, vol.39, iss. 5, p:28.

Didar, $\mathrm{H}$; Imani B, M; Shahrezaei, S. Effect of business diversification on performance of Tehran security exchange accepted companies, 2014, Asset management and financinf, N2.

Fazl zadeh, A; Khanlari, M; Teimouri, H. examining the relationship between business diversification, capital structure, free cash flow and performance of Tehran security exchange accepted companies, 2014, national conference of new methods in business management.

Harash,E; Al-Timimi, S \& Alsaad, J. The Influence of Finance on Performance of Small and Medium Enterprises (SMES), 2014, International Journal of Engineering and Innovative Technology (IJEIT) Volume 4, Issue 3.

Heron; randall, A \& erik, lee. a comparison of the motivation for and the information content of different types of equity offerings, 2004, journal of business, 77, p:605-632.

Kang, K; Lee, S; Yang, H. The Effects of Product Diversification on Firm Performance and Complemenarities between Products, 2011, International Journal of Hospitality Managemebt 409-421.

Kazeruoni, A \& Harighy M.F. Diversification of business transactions and its effects on economic growth in Iran, 2005, business research book, ninth year, $\mathrm{N} 36$.

Kordestani, GH \& Najafi omran, M, Reviewing the financing methods impact on stock future income, Accounting progressive, 2010, N2, Pp 75-108.

Maleki nejad, Affect of performance Diversification of small and average industries on economic improvement, 2006, Rahbord journal, N8, pp 41 to 170.

Mclaughlin, robyn, assem safieddine, \& gopala K. Vasudevan, the operating performance of seasoned equity issuers: free cash flow and post issue performance, 1996, financial management, 25(4),p:41-53.

Mojtahed zadeh, V; Alavi T, S.H; Khodabahkshi, N. Relationship between financing and operating performance in of Tehran security exchange accepted companies, 2009, accounting researches, N1.

Molla nazari, M; Hejazi, R; Sahraei, M. Examining the relationship between financing methods and success and non- success of Tehran security exchange accepted companies, 2010, financial accounting and auditing researches, N6.

Nath, P; Nachiappan, S; Ramanathan, R. The impact of marketing capability, operations capability and diversification strategy on performance: A resource-based view, 2010, Industrial Marketing Management, Volume 39, Issue 2, February 2010, Pages 317329.

Rouhi, A., Tavangar, A \& Mohammadi, M. (2013). The impact of financing method on performance of private banking industry.Management Science Letters , 3(2), 547-554.

Sheikh, M.J; Hemmati, H; Zamani G, M; Mohajerani, M. Check the effect of business diversification on financial performance of Tehran security exchange accepted companies, 2014, accounting and auditing researches, N22.

Taghy pour, A. Relationship between Diversification and income stability, 2003, business research book, N19, pp 63 to 94 .

Taheri, SH. Efficiency and its analyzing in organizations (total efficiency management), Tehran, Hastan, 2008, first publishing, p9.

Tehrani, R. diversification on financial performance strategy, 2007, financial researches, N25, pp 21 to 40. 
Tehrani, R \& Vahed. A, H. study of relationship between products diversification with stock's risk and return of productive companies in Tehran security exchange, 2006, business research book, N 38.

Tehrani, R; Babaie Z, M.A; Karimi, K. The effect of diversification strategy on financial performance of Tehran security exchange companies, 2008, financial researches, N25, pp 21. 